\title{
Masonería, historia y memoria: la cuestión de los Orígenes
}

\author{
Freemasonry, history and memory: the question of origins
}

\author{
Dévrig Mollès \\ devrigmolles@gmail.com \\ Doutor em História \\ Université de Strasbourg (França) \\ Chile 2546, 4 \\ 1227 - Buenos Aires \\ Argentina
}

\begin{abstract}
Resumo
O artigo trata da maçonaria e seus "mitos de origem". É uma contribuição ànova historia científica da maçonaria desenvolvida na América Latina desde os anhos 2000 seguindo as influenzas francesas e espanholas. Com os melhores especialistas da história da maçonaria, e com os instrumentos da sociologia do conhecimento e da historia das ideologias, resume as origens das duas grandes neo-tradições disponíveis sobre as origens da maçonaria. Em seguida, o artigo busca refletir sobre os fundamentos ideológicos destas neo-tradições; sonda de forma preliminar alguns dos usos militantes que tiveram no século $X X$, vislumbrando uma relação entre o mito da origem antiga e a moderna ideologia do progresso por um lado, e entre o mito das origens medievais e a ideologia tradicionalista, reacionária ou conservadora por outro lado. Neste aspecto, o artigo só abre o caminho para um estudo mais amplo e sistemático, cujas bases - genealogia, história e sociologia - são propostas na conclusão.
\end{abstract}

\section{Palavras-chave}

Memória coletiva; Ideologia; Historiografia.

\begin{abstract}
The article deals with Freemasonry and its myths of origin. It is a contribution to the new scientific history of Freemasonry developed in Latin America since the 2000, in response to the French and Spanish influences. From the best specialists of Freemasonry, of sociology of knowledge and of the history of ideologies, the origins of the two large neo-traditions available on the origins of Freemasonry (the myths of ancient origins and medieval origins) are summarized. Then, the article seeks to reflect on the ideological foundations of these neo-traditions. It polls in a preliminary way some variants and militant applications that resulted from this neo-traditions during the 20th century, glimpsing a link between the myth of the ancient origins and modern ideology of progress on the one hand, and between the myth of medieval origins and traditionalist, reactionary or conservative ideology on the other hand. At this point, the article only paves the way for a broader and more systematic study whose bases are proposed in the conclusion.
\end{abstract}

\section{Keywords}

Collective memory; Ideology; Historiography.

Recibido el: 25/5/2015

Aceptado el: 17/5/2016 
Frecuentemente evocada pero marginal en la historiografía universitaria generalista (MOLLĖS 2014), la franc-masonería solo se constituyó como objeto de investigaciones científicas a partir de 1950-1960 en Francia. Desde 1970-1980, científicos españoles, británicos y estadounidenses han reforzado esta dinámica. Desde los años 2000, las influencias francesas y españolas convergieron hacia América latina, generando por primera vez publicaciones científicas, una revista científica y congresos internacionales. ${ }^{1}$ Lejos de haber agotado la cuestión, esta nueva escuela comenzó a explorar un iceberg desconocido. Lidia con una pesada herencia: abandonada durante mucho tiempo a militantes y aficionados, la cuestión masónica suscitó en América latina innumerables supercherías y simulaciones.

Entre mitos fundadores y leyendas apócrifas, el mundo masónico carga pesadas anclas, un folklore anquilosado del que es preciso librarse para adquirir lucidez. Abordada durante décadas en los márgenes de las ciencias sociales, concebida como un fenómeno aparte por los militantes y poco estudiada por los sociólogos e historiadores, la cuestión masónica quedó frecuentemente librada a fantasías que ocultaban la carencia de formación científica o la voluntad de manipulación ideológica. Esta cuestión, sin embargo, ¿no es susceptible de análisis utilizando los métodos de la historia social y de la sociología histórica, como lo son todas las instituciones sociales?

De todos los debates relativos a la historia de la francmasonería, la cuestión de los orígenes es uno de los principales. Es, quizás, la que ha generado la mayor cantidad de leyendas apócrifas. Los mejores especialistas lo subrayaron: la masonería fue una invención del Siglo de las Luces; no se relacionaba con las lejanas tradiciones antiguas o medievales sino por alegorías y símbolos (RÉVAUGER 2013, p. 33; DACHEZ 2008). No obstante, el desfasaje entre historia y memoria es notable, muy particularmente en las Américas. Pese a los inmensos avances realizados por los profesionales de las ciencias sociales, los relatos pseudohistóricos perduran en la memoria colectiva de los no-masones $y$, sobre todo, de los masones. Influyen en sus representaciones colectivas, a la vez que orientan el perfil de reclutamiento. Este texto procura una clarificación: ¿cuáles son las matrices de estos relatos? ¿Con qué perfiles sociológicos e ideológicos se relacionan?

\section{La invención de la tradición: Las neotradiciones}

Estos mitos, ¿remiten a una "invención de la tradición" (HOBSBAWM; RANGER 1983)? Más que del pasado, las neotradiciones hablan de la época en que son inventadas. Crecen a partir de nuestra necesidad de compartir imaginarios y memorias que nos identifiquen y nos incluyan en una comunidad imaginaria. Proveen una suerte de seguridad simbólica, funcionan como referencias estables en el cambio permanente, en la "modernidad líquida" (BAUMAN 2003), en la

\footnotetext{
${ }^{1}$ La revista puede consultarse en: http://rehmlac.com/. Una síntesis en: Ferrer Benimeli (2012); Martínez Esquivel (2013). Para Brasil, entre los nuevos autores, véase a los brasileiros C. M. Marinho de Azevedo (2010), A. Mansur Barata (2013), M. Morel (2008), M. Goulart (2015) y, desde una perspectiva atlántica incluyendo Brasil, Argentina y México, al francés D. Mollès (2013). Sobre los congresos de 2014 y 2015: Del Solar (2014); REHMLAC (2015).
} 
gran aceleración del tiempo, en la urbanización acelerada y en la disolución de las comunidades tradicionales.

En las comunidades reducidas de la Antigüedad, las condiciones de vida permanecían inalterables por siglos. La tradición y el sentido común que el individuo había obtenido de sus predecesores y de su experiencia eran suficientes para mostrarle su lugar y sus funciones en la sociedad. Pero hoy, en "una sociedad cuyo mercado abarca el mundo entero, que está en proceso de constante transformación, de revolución industrial y social" (KAUTSKY 2013, p. 23-24), estas comunidades tradicionales se han disuelto. El individuo no puede apoyarse ni en ellas ni en su sentido común para adaptarse.

De allí un sentimiento de vacío y el deseo de crear nuevas comunidades de referencia. En determinados contextos, algunos de estos vacíos pudieron ser rellenados por tradiciones inventadas. En una obra clásica, Eric J. E. Hobsbawm y Terence Ranger (1983, p. 1-16) clasificaron estas neotradiciones en tres tipos dominantes: a) las neotradiciones que establecen e instituyen comunidades (reales o artificiales), otorgándoles mitos fundadores e identidades colectivas; b) las neotradiciones que establecen o legitiman instituciones, estatus sociales o relaciones de poder; c) las neotradiciones destinadas al adoctrinamiento éticoideológico. Mito fundador, fuente de identidad colectiva, fuente de legitimidad o guía ético-ideológica, la neotradición es frecuentemente el producto de operaciones de manipulación sobre la memoria -que no debe confundirse confunde con la historia (LE GOFF 1990). El nacionalismo moderno y sus "comunidades imaginadas" constituyen un buen ejemplo (ANDERSON 1983; SMITH 1991). Todas las naciones modernas se autoconstituyeron a partir de experiencias fundadoras como la Revolución inglesa (1689), la Revolución francesa (1789) y las Independencias americanas. No obstante, durante los siglos XIX y XX, tanto en Europa como en América, los nacionalismos modernos procuraron crear $y$ consolidar el sentimiento nacional cultivando ciertos mitos de orígenes antiguos. Los rituales desplegados por la monarquía británica en sus ceremonias públicas ofrecen otro ejemplo. Aunque se revistan solemnemente de todos los signos de antigüedad, fueron inventados, en su forma actual, durante los siglos XIX y XX (CANNADINE 1983).

Así, una tradición que se pensaba inmemorial era la creación reciente de un grupo humano concreto, localizado en el espacio y en el tiempo. Así, una tradición que se pensaba fija, invariable y sagrada gozaba en realidad de una asombrosa plasticidad, adaptándose a las necesidades de un tiempo presente.

\section{La invención del texto fundador de la masonería}

Publicadas por primera vez en Londres en 1723, The Constitutions of the Freemasons no escaparon a estos procesos. Texto fundador de la masonería, permanecen mal conocidas y superficialmente leídas en América Latina. ¿Cómo explicarlo? Por cierto, las Constituciones fueron ampliamente difundidas en el mundo anglófono desde el siglo XVIII. Agotada en 1735, la edición inglesa de 1723 fue modificada e impresa cuatro veces entre 1738 y 1784 . En la colonia norteamericana de Pennsylvania, Benjamin Franklin imprimió y difundió el 
texto por primera vez en 1734. Lejos de ser monolítico, este texto evolucionó, desplegando progresivamente cierto imaginario social. Así, cuando la primera versión de 1723 contaba con 110 páginas, la quinta y última totalizó 484 páginas. ${ }^{2}$

Sin duda, las Constituciones fueron esenciales en la formación de las primeras generaciones masónicas inglesas. Como lo mostró uno de sus mejores conocedores, el francés Maurice Paillard, ${ }^{3}$ este volumen de la ley masónica fue el único libro utilizado por la primera Grand Lodge of England durante sus ceremonias, excluyendo todo otro "Libro de la Ley Sagrada" como la Biblia. Colocadas sobre un cojín de terciopelo, escoltadas por el venerable maestro de la logia más antigua de la federación, las Constituciones precedían inmediatamente al gran maestro en la ceremonia de su instalación como primer dignitario de la cofradía. Este libro, aún en su cojín de terciopelo, se le presentaba - junto a una espada y colocado en un pedestal - para prestar juramento. El símbolo -revolucionario para la época - era evidente: el dignatario gobernaba, las Constituciones regían.

¿Cómo explicar, después de 300 años, el conocimiento superficial que tiene hoy de ellas el público masónico latinoamericano? Este texto fundador parece haber ingresado tardía y superficialmente en su horizonte. Una amplia experiencia de los archivos latinoamericanos sugiere que, hasta hoy, este texto fundador permaneció reservado, sin difusión entre los propios masones. ${ }^{4}$ ¿Por qué? En realidad, fuera del mundo anglófono, las Constituciones circularon poco y no parecen haber desempeñado un papel significativo hasta el siglo XX. Pese a algunas traducciones al francés (1742) y al alemán (1741), su papel en Europa 142 continental fue, a lo sumo, modesto durante el siglo XVIII. ${ }^{5}$ Casi olvidadas durante décadas, fueron en realidad reinventadas por la derecha católica durante los años 1930. Monseñor Jouin - editor de la Revue Internationale des Sociétés Secrètes (subtitulada "órgano antijudeomasónico") - vio en ellas la prueba decisiva: la masonería era un agente del liberalismo cosmopolita y disolvente, cuyos valores se hallaban en los orígenes de la Revolución francesa, de la Tercera República y del Estado laico (ANDERSON; DÉSAGULIERS; JOUIN 1930). Encantados, los masones franceses se reapropiaron de las Constituciones, las reinventaron, publicando después de la Segunda Guerra Mundial una nueva traducción comentada (PAILLARD 1938, 1952). Con ello, legitimaban su tradición librepensadora frente al conservadurismo que - desde fines del siglo XIX (RÉVAUGER 2013) - se había apoderado de sus homólogos ingleses y norte-americanos.

En su estela, ¿redescubrieron el texto fundador los masones latinoeuropeos y latinoamericanos? Nada permite afirmarlo. Durante el siglo XIX, la influencia francesa había sido vigorosa en América latina, fuera y dentro de la esfera

\footnotetext{
2 Las ediciones inglesas fueron realizadas en $1723,1738,1756,1767$ y 1784. La primera edición americana fue realizada en 1734 en Filadelfia. Una aproximación genealógica en: Ligou (1998, p. 303); Mollès (2015a, p. 20-22).

3 Maurice Paillard $(1952$, p. 29-31, 41) comparó las cinco ediciones y analizó más de 242 actas de reuniones del Consejo de la primera Grand Lodge of England (de 1717 a 1783). Enseñó el papel central de las Constituciones en las ceremonias de esta organización y mostró que la palabra «Biblia» solo fue utilizada en la parte pseudohistórica de las Constituciones (en sus cinco versiones de 1723 a 1784). Solo pudo rastrear un caso de utilización ceremonial de la Biblia, durante una ceremonia pública el 23 de mayo de 1776.

${ }^{4}$ El ejemplar más antiguo localizado por ahora entre México, Brasil, Uruguay, Chile, y Argentina está conservado en el Archivo de la Gran Logia Argentina. Se trata de una versión en inglés, impresa en New York en 1859.

${ }^{5}$ Sigo aquí dos especialistas del siglo XVIII: Porset (1999) y Önnersfors (2010, p. 12).
} 
masónica (MOLLÈS 2011). Entre las dos Guerras mundiales, los fascismos habían destruido todas las masonerías latinas; después de 1945, algunas se reconstituyeron con dificultad, en Francia e Italia esencialmente (MOLLÈS 2007). Su influencia en América latina estaba tomada en un ciclo estructural confirmado por la Segunda Guerra mundial: el retroceso del modelo francés y el auge de la influencia estadounidense (ROLLAND 2000; ROCK 1994).

\section{Mitos, leyendas, alegorías... ¿iideologías? Los orígenes antiguos}

Aún revestida de los paramentos simbólicos de la ciencia y de la verdad, la masonería nació entre historia y memoria. Su texto fundador, publicado en Londres en 1723, ya procuraba una identidad y una legitimidad para la naciente cofradía. En la introducción de The Constitutions of the Free-Masons, su editor - un exiliado protestante francés de 40 años, entonces vice gran maestre de la Grand Lodge of London and Westminster y asistente de Isaac Newton en la Royal Society (MOLLÈS 2015b) - aseguraba entregar a los lectores "una relación fiel y exacta de la Masonería desde el Comienzo del mundo". Solapadamente, no obstante, admitía el carácter contemporáneo de esta relación. De los "viejos archivos", solo se había conservado "[...] lo que de las antiguas Constituciones era verdaderamente antiguo y auténtico". Este contenido seleccionado se había redistribuido de acuerdo con "la Historia y la Cronología" (ANDERSON; DÉSAGULIERS 1723, p. II-III). ${ }^{6}$ Así, más allá de las afirmaciones realizadas, la verdadera autenticidad y la verdadera tradición eran construcciones irremediablemente modernas. A través de un relato leyendario -que hoy "no puede ser considerado seriamente" (LIGOU 1998, p. 303) -, la joven masonería se presentaba como heredera de una antigua tradición científica. Este neopasado hundía sus raíces en la creación del mundo, que en esta época remontaba a 4003 años antes de Cristo:

Año del Mundo I, 4003 antes de J.C.:

Adam, nuestro primer Ancestro, creado a imagen de Dios, el gran Arquitecto del Universo, debió tener las Ciencias Liberales, particularmente la Geometría, grabadas en su Corazón; porque desde la misma Caída, hallamos estos Principios en el Corazón de sus Descendientes, Principios que, a través del tiempo, han sido reunidos en un eficiente Método (ANDERSON; DÉSAGULIERS 1723, p. 1). ${ }^{7}$

Esta antigüedad primigenia confería nobleza e identidad. La masonería era la legítima heredera de una tradición inmemorial, anterior a todas las demás:

En resumen, varios y gruesos Volúmenes serían necesarios para contener los múltiples y espléndidos Ejemplos de la poderosa Influencia de

\footnotetext{
${ }^{6}$ En el original: "in compiling and digesting this Book from the old Records [...] and made every thing agreeable to History and Chronology, so as to render these New Constitutions a just and exact Account of Masonry from the Beginning of the World [...] still preserving all that was truly ancient and anthentick in the old ones."

7 En el original: "Adam, our first Parent, created after the Image of God, the great Architect of the Universe, must have had the Liberal Sciences, particularly Geometry, written on his Heart; for even since the Fall, we find the Principles of it in the Hearts of his Offspring, and which, in process of time, have been drawn forth into a convenient Method of Propositions."
} 
la Masonería desde la Creación, en cada Época y en cada Nación [...] Porque realmente ningún [otro Arte] es más generalmente útil a la Humanidad [...] Hasta podríamos, si fuese más expediente, enseñar que las Sociedades u Órdenes Militares de Caballería, y de Religiosos también, han -en el tiempo- tomado prestados numerosos Usos Solemnes a esta antigua Cofradía (1723, p. 44-46). ${ }^{8}$

Con un método científico y una filosofía universalista por trasfondo, el relato mítico estaba tejido de anacronismos. De Oriente a Occidente, desfilaban África y Asiria, Egipto y Jerusalén, Grecia, Sicilia y Roma. Atada a la historia de la arquitectura, de los grandes monumentos y de los reyes antiguos, la antigua cofradía había preservado la geometría, el dibujo, las artes mecánicas y la albañilería. De allí había desembarcado en Francia y luego en Inglaterra y Escocia, donde reyes y señores la habían cobijado.

Desplegado en símbolos y parábolas, su mito fundador no era, como suele pensarse, la leyenda de Salomón y de Hiram Abif. El rey y el arquitecto integraban una alegoría más vasta y profunda: la Torre de Babel, símbolo de la dispersión de la humanidad. Así comenzaba la historia leída en la recepción de todo nuevo hermano. En el principio, Adán había cultivado las ciencias y las artes. Luego la Caída, sus descendientes habían perpetuado "la noble Ciencia" e inventado "un Método" experimental, fundado en las "proposiciones" y "la observación de las Leyes". Después de 1656 años, el Diluvio había sumergido el viejo mundo. La humanidad aún hablaba el mismo idioma. Se había lanzado a la aventura de la Torre de Babel, para alcanzar los cielos. Celoso de su monopolio, Dios había perturbado su empresa, dividiéndo el lenguaje común en varios idiomas. La confusión de los discursos había precedido la "Gran Dispersión" y la fragmentación en múltiples "Reinos, Repúblicas y Dinastías". En este preciso punto había nacido la masonería, para reunir la humanidad dispersa. A través de los siglos, esta cofradía había preservado el patrimonio común de la humanidad: "la Ciencia y las Artes [...] transmitidas a las Edades posteriores y en Regiones alejadas, a pesar de la Confusión de los Idiomas o de los Dialectos".9 Algunas regiones, sin embargo, habían sido precipitadas en la decadencia por "los Estragos de la Guerra y porque no mantuvieron las Relaciones deseables con las Naciones refinadas e instruidas". ${ }^{10}$ En este preciso momento entraban en escena los "Extranjeros" quienes, gracias a sus "Peregrinaciones", habían diseminado y perfeccionado el Saber original; pueblo tras pueblo, transmisión tras transmisión, habían perfeccionado la Ciencia y contribuído al progreso de la humanidad (ANDERSON; DÉSAGULIERS 1723, p. 1-7).

Salomón e Hiram integraban una alegoría: el mito de la Torre de Babel. ¿Cuál era su sentido profundo? La humanidad era una sola, pese a su fragmentación

\footnotetext{
${ }_{8}^{8}$ En el original: "In short, it would require many large Volumes to contain the many splendid Instances of the mighty Influence of Masonry from the Creation, in every Age and in every Nation, as could be collected from Historians and Travellers [...] as indeed none other is so extensively useful to Mankind [...] Nay, if it were expedient, it could be made appear, that from this ancient Fraternity, the Societies or Orders of the Warlike Knights, and of the Religious too, in process of time, did borrow many solemn usages."

${ }^{9}$ En el original: "From hence, therefore, the Science and Art were both transmitted to latter Ages and distant Clime, notwithstanding the Confusion of Languages or Dialects".

${ }^{10}$ En el original: "Until their original Knowledge was almost lost by the Havock of War, and by not maintening a due Correspondenca with the polite and learned Nations".
} 
lingüística, religiosa y política. La ciencia y las artes eran su común patrimonio. Su decadencia eran la guerra y el aislamiento internacional. Su progreso y su felicidad exigían el intercambio y la libre circulación de los conocimientos y las técnicas.

La masonería había nacido para reunir lo disperso. ¿Pero cómo ser un asilo del género humano? Era preciso superar las divisiones sectarias que tanto daño habían causado a Europa, dividida entre la Reforma protestante y la Contrarreforma católica. La masonería era el templo cosmopolita de una nueva religión de la humanidad

"Religión sobre la cual todos los Hombres concuerdan, dejando a cada uno sus propias Opiniones; es decir, ser Hombres de bien y leales, Hombres de Honor y de Probidad, cualesquiera sean las Denominaciones o Confesiones que ayudan a distinguirlos" (ANDERSON; DÉSAGULIERS 1723 , p. 50). ${ }^{11}$

La logia masónica nacía pues como un espacio público laico y cosmopolita. Era el "centro de unión" entre hombres de distintas nacionalidades, religiones, condiciones y sensibilidades. Para mantener la armonía, "ninguna Enemistad o Querella privada" debía trasponer su umbral, "menos aún Querellas sobre la Religión, las Naciones o las Políticas de Estado" (1723, p. 54). Solo se rendiría culto a "la Libertad de Conciencia [...] la noble Ciencia y [...] las Virtudes Sociales" (1738, p. V). Las logias eran laboratorios para una nueva ética secular y humanista. Sus creadores eran científicos ingleses y exiliados franceses, de distintas confesiones protestantes (MOLLÈS 2015b, p. 194-197); asumían el programa de la Royal Society, el verdadero crisol de la masonería, cuya meta consistía - según el obispo Thomas Spratt, su primer historiador (1667) - en congregar a

hombres de distintas religiones, de distintos países y de distintas profesiones [...] porque preconizaba abiertamente establecer los cimientos, no de una filosofía inglesa, escocesa, irlandesa, papista o protestante, sino de una filosofía del género humano (apud GOULD 1936 II, p. 99). ${ }^{12}$

\section{Los orígenes medieval-caballerescos}

Las Constituciones de 1723 inventaron los orígenes antiguos, científicos y humanistas. Prolífico y fantasioso, el siglo XVIII también inventó los orígenes medievales, el 26 de diciembre de 1736. Su autor - un católico escocés emigrado en Francia - tenía 50 años. Preceptor apreciado por la aristocracia parisina, el caballero Andrew Michael Ramsay publicaba exitosas novelas de viajes iniciáticos y religiones enigmáticas. Las Constituciones de 1723 habían plasmado el mito del origen antiguo-artesanal. Ramsay le sustituyó el mito del origen medieval, caballeresco y católico:

\footnotetext{
${ }^{11}$ En el original: "that Religion in which all men agree, leaving their particular Opinions to themselves; that is to be good Men and true, or Men of Honour and Honesty, by whatever Denominations or Persuasions they may be distinguish'd."

${ }^{12}$ En el original: "men of differente religions, countries and professions of life [...] For they openly profess not to lay the foundation of an English, Scottish, Popish o Protestant philosophy - but a philosophy of mankind."
} 
En el tiempo de las Cruzadas en Palestina, muchos Príncipes, Señores y Ciudadanos entraron en Sociedad y se comprometieron a restaurar los Templos de los Cristianos en Tierra Santa [...] Se pusieron de acuerdo sobre signos antiguos y palabras simbólicas, extraídos de las profundidades de la Religión, para reconocerse entre sí y distinguirse de los Infieles y Sarracenos [...] Estos compromisos sagrados, por lo tanto, no eran una blasfemia execrable, como se ha sugerido, sino un respetable vínculo que une a los Cristianos de todas las Naciones en la misma Fraternidad. Tiempo más tarde, nuestra Orden se vinculó estrechamente a los Caballeros de San Juan de Jerusalén. Desde entonces, nuestras logias son llamadas Logias de San Juan. Esta unión siguió el ejemplo de los Israelitas, cuando construían el segundo Templo. Mientras sostenían la paleta y el mortero en una mano, en la otra sostenían la espada y el escudo (RAMSAY apud MOLLIER 2014, p. 84-85). ${ }^{13}$

¿Cómo explicar este giro narrativo? Sin duda, Ramsay se adecuaba al gusto literario del siglo XVII y de los inicios del siglo XVIII. Escritor y comerciante de libros, respondía a la pasión que los reducidos círculos de lectores de la época mantenían por las novelas de caballería. Muy a tono con este gusto, adaptó el relato de los orígenes y declamó sobre los monjes-soldados cruzados del siglo XII. Por supuesto, eligió la más antigua de todas las Órdenes militares: Ios Caballeros de San Juan. ${ }^{14}$

El texto se insertaba en un contexto. Discípulo de Fenelón, Ramsay seguía un camino cristiano-místico: el quietismo, muy difundido en los siglos XVII y XVIII, aunque condenado como herético por la Iglesia católica en 1687. Quizás reforzaba su propia identificación con la masonería inventándole orígenes medievales y cristianos. Por otra parte, y por, sobre todo, Ramsay presentó su discurso al cardenal de Fleury, principal ministro del joven rey Luis XV - el obispo de los obispos en Francia - y hombre fuerte del Estado francés. Las logias comenzaban a desarrollarse. El poder político había empezado a manifestar cierta suspicacia; el 17 de marzo de 1737, había prohibido estas asambleas. En la carta adjunta a su discurso poco después, Ramsay solicitaba a Su Majestad tolerancia y protección para la cofradía que, decía, deseaba servir a la religión, al Estado y a las letras. El relato caballeresco y cristiano probablemente le proveía cierta legitimidad aristocrática y católica. No obstante, su tentativa fracasó. El cardenal de Fleury simplemente respondió que estas asambleas disgustaban al rey y procedió a un simulacro de represión. Ramsay se retiró definitivamente de la masonería (COMBES 1998, p. 21-22).

\footnotetext{
${ }_{13}^{13}$ La cita corresponde à la versión definitiva del discurso (inicios de 1737), reproducida en La Tierce, Histoire, obligations et statuts de la Très Vénérable Confraternité des Francs-Maçons, Francfort-sur-le-Meyn, 1742, por (MOLLIER 2014, p. 84-85). «Du temps des guerres saintes dans la Palestine, plusieurs Princes, Seigneurs et Citoyens entrèrent en Société, firent voeu de rétablir les temples des Chrétiens dans la Terre Sainte [...] Ils convinrent de plusieurs signes anciens, de mots symboliques tirés du fond de la religion, pour se distinguer des Infidèles, et se reconnoître d'avec les Sarasins. On ne communiquoit ces signes et ces paroles qu'à ceux qui promettoient solemnellement et souvent même au pieds des Autels de ne jamais les révéler. Cette promesse n'étoit donc plus un serment exécrable, comme on le débite, mais un lien respectable pour unir les hommes de toutes les Nations dans une même confraternité. Quelques temps après, notre Ordre s'unit intimement avec les Chevaliers de S. Jean de Jérusalem. Dès lors et depuis nos Loges portèrent le nom de Loges de S. Jean dans tous les pays. Cette union se fit en imitation des Israélites, lorsqu'ils rebâtirent le second Temple, pendant qu'ils manioinent d'une main la truelle et le mortier, ils portoient de l'autre I'Epée et le Bouclier.»

${ }_{14}$ Posteriormente llamado de Rodas en el siglo XIV y de Malta desde el siglo XVI. El nombre actual de esta Órden es Soberana Orden Militar y Hospitalaria de San Juan de Jerusalén, de Rodas y de Malta. Sobre el discurso de 1736. Véase (LASSALLE 2003)
} 


\section{Los orígenes templarios}

Más allá de la política, no obstante, quedaba una huella imaginaria. Pese a su fracaso político, Ramsay dejó en el imaginario colectivo el brote de una nueva neotradición. Pese a la monarquía francesa, popularizó una idea: la masonería no era una fraternidad civil sino una orden de caballería. Este relato alimentó el naciente imaginario de la naciente masonería francesa. La creencia se esparció por los países que mantenían relaciones con sus logias, como Alemania, Italia, Suecia y Rusia. Las variantes de este discurso proliferaron a borbotones. Con el tiempo, el núcleo primigenio se fragmentó en mil microcosmos imaginarios. La galaxia de los Templarios fue el principal. ¿Cuáles fueron sus planetas y cometas?

La Orden del Temple había sido destruida en 1314. El Papa Clemente V y el rey Felipe el Bello de Francia habían condenado a sus miembros por herejes, pretexto entonces habitual para el despojo y la destrucción de rivales políticos o económicos. Perseguidos, los Templarios habían entonces huido. Se habían refugiado en Escocia. En este pequeño reino norteño, lejos de Roma y de París, las logias masónicas operativas los habrían cobijado. Así, los Templarios habrían sobrevivido secretamente durante 400 años gracias al apoyo de la dinastía reinante. Una historia fascinante, como lo recordaba recientemente Pierre Mollier, un gran conocedor de la cuestión:

Es una linda historia... pero no existe un solo hecho histórico serio para sustentarla [...] Para los historiadores que estudian el Medioevo, no existe un solo documento, un solo indicio que pueda sustentar la hipótesis según la cual los Templarios sobrevivieron de una u otra forma [...] En la propia Escocia, el tema templario parece haber tocado muy tardíamente a la masonería (MOLLIER 2014, p. 82-83, 85). ${ }^{15}$

En realidad, la leyenda de los Templarios apareció por primera vez "en un ritual masónico, una antigua versión del grado de Caballero Kadosh, fechada en 1750" (MOLLIER 2014, p. 88). No puede invocarse "ninguna prueba [...] ningún vínculo" (HARRISON 2014) ${ }^{16}$ de ningún tipo para relacionar masonería y templarios. El consenso científico sobre este punto es absoluto. Según David Stevenson, el principal especialista mundial de la masonería en Escocia:

Las afirmaciones acerca de una relación entre los Caballeros Templarios o los Rosacruces (si es que estos realmente existieron) y la formación de la Francmasonería deben ser rechazadas como extremadamente fantasiosas (para permanecer dentro de los límites de la cortesía) (STEVENSON 2014, p. 61). ${ }^{17}$

\section{Los usos militantes del mito: Los orígenes antiguos y la ideología del progreso}

Flexibles y polimórficas, las neotradiciones se adaptan a las intenciones más diversas. El mito de los orígenes antiguos sirvió admirablemente a los

\footnotetext{
15 Pierre Mollier es director del Archivo histórico del Gran Oriente de Francia.

${ }^{16}$ En el original: "There is no evidence whatsoever assuming to the Knight Templars as an Order, a Masonic Order [...] no links at all with Medieval Knight Templars".

17 En el original: "Claims of the involvement of the Knights Templar o the Rosicrucians (if, indeed, the latter ever really existed) in the formation of Freemasonry may be dismissed (to be polite) as fanciful in the extreme."
} 
partidarios de la modernización, del cambio y del progreso. Los filósofos del siglo XVI, XVII y sobre todo XVIII, por ejemplo, encendieron las luces de la filosofía natural y de la democracia antigua para alumbrar tiempos de oscurantismo y absolutismo. Cementaron nuevas representaciones colectivas, nutriendo una nueva cultura política que, a partir de la Revolución francesa, irrigó el siglo XIX.

En São Paulo, en 1921, esta huella seguía viva. María Lacerda de Moura daba conferencias sobre los orígenes de la masonería. Esta joven intelectual, profesora de escuela normal, se interesaba por la teosofía, era feminista y librepensadora. Su padre era un viejo masón socialista. Ella se había involucrado en las logias mixtas del Derecho Humano, una rama de la masonería francesa. ${ }^{18}$ Por primera vez, quizás, se expresaba en una logia masculina, también francesa.

Sin referirse a las Constituciones de 1723, reseñaba la antigüedad inmemorial de la cofradía, partiendo de los antiguos misterios egipcios, griegos, hindúes o celtas. Según ella, "los faraones, Salomón, Hermes, Rama, Krishna, Sócrates, Orfeo, Pitágoras, Jesús Cristo, fueron iniciados". En el antiguo Egipto, "las Logias Masónicas [...] no tenían más de 40 miembros". Allí, por ejemplo, "la mujer participaba en estos trabajos [...] derechos iguales y obligaciones iguales le eran otorgados". Asimismo, en la "tradición celta", la mujer era considerada como "una compañera y no como una subalterna". Después de este período de fastos había caído una "noche de mil años". La noble tradición masónica de "investigación de la ciencia" había sido dispersada por las "religiones sectarias". Las mujeres habían sido "alejadas [...] quizás por influencia de las Corporaciones de trabajadores, durante el Medioevo" (LACERDA DE MOURA 1922, p. 9, 16, 18, 20).

Esta crónica era totalmente imaginaria, pues "no se puede relacionar el culto de Isis o los misterios de Eleusis con la futura masonería sino por analogía" (COMBES 1998, p. 7). No obstante, plantea una pregunta: ¿cuál era su significado cultural e ideológico? Demostraba que la masonería era anterior a la "Iglesia Romana", definida como fuente de opresión, superstición, oscurantismo y esclavización del género femenino. En los tiempos primigenios, la antigua cofradía había reunido a los Hijos e Hijas de la Luz, una élite espiritual e intelectual reclutada entre hombres y mujeres. Perseguidos durante siglos por la Sombra del fanatismo, los masones habían olvidado sus orígenes. Desde la Revolución francesa, y más aún en el inicio del siglo $X X$, peleaban nuevamente entre Luz y Sombra. La emancipación no debía limitarse al género femenino, sino extenderse a las clases obreras y, más allá, a "toda la humanidad". Hijos de la Luz, los masones libraban desde siglos este combate por la "libertad, igualdad, fraternidad". Para triunfar, debían retornar a sus antiguas raíces tradicionales, reintegrar a la mujer y librar por fin la gran batalla final por la "república humana, la fraternidad internacional", "la abolición de la esclavitud femenina", "la igualdad de los derechos en el Código para ambos sexos", "la proclamación de los Derechos Humanos", "la justicia social" (LACERDA DE MOURA 1922, p. 18, 33, 34, 23, 28, 42). 


\section{Los orígenes medievales y la ideología de la conservación o de la reacción}

El mito de los orígenes antiguos sirvió frecuentemente a la causa de la modernidad y del progreso. Por el contrario, el mito de los orígenes medievales sirvió a la causa de la reacción y el conservadurismo. Desde mediados del siglo XVIII, y más aún después de 1789, la aristocracia prusiana buscó en el romanticismo neomedieval un dique contra la filosofía moderna que minaba su hegemonía. Sus poetas, eruditos y bardos exaltaron las jerarquías y la religión, que constituían el alfa y el omega de la tradición feudal.

¿Por qué mencionarlo? Se trata de una cuestión actual. A través de un largo recorrido, el relato neomedieval reapareció por ejemplo en Buenos Aires en 2004. En un texto mitológico y alucinado, el narrador Eduardo Callaey sostenía por ejemplo la teoría de una "alianza inaudita" entre órdenes monásticas, órdenes militares y corporaciones medievales para explicar el origen de la masonería y su supuesta "esencia" (CALLAEY ARRANCIBIA 2005, cap. 1). De la orden monástica de San Benito, fundada en el siglo VI, había surgido una primera "masonería benedictina" (CALLAEY ARRANCIBIA 2005, cap. 6), posteriormente integrada al servicio de los Templarios, creados durante la primera "peregrinación armada a Tierra Santa". ${ }^{19}$ Llegado a este punto de fantasía, se podía teorizar sobre una "transición de la masonería benedictina a la futura masonería operativa" (CALLAEY ARRANCIBIA 2006, p. XIII, XVI), a los "constructores de catedrales" (CALLAEY ARRANCIBIA 2005, cap. 6) y luego de "la francmasonería operativa a la francmasonería especulativa". ${ }^{20}$ Así, algunos narradores argentinos del siglo XXI habían descubierto entre monjes, templarios y masones europeos una filiación que, curiosamente, había escapado a los historiadores y sociólogos europeos y americanos.

Reivindicando "las novelas de caballería"21 por modelo, convocaron todos los recursos de la imaginación. A la manera del Código da Vinci, se remontaron a los Carolingios, sopesando las "múltiples razones" (CALLAEY ARRANCIBIA 2004, cap. VI.1) que, según ellos, permiten atribuir la invención de la masonería a Carlomagno o a Carlos Martel en el siglo IX. Confundían tiempos y mundos inconmensurables. Compartían una concepción esencialista: Ios fenómenos estudiados poseían características intangibles, una "esencia" (CALLAEY ARRANCIBIA 2005, p. 1). Para demostrarlo, recurrían a la técnica de "la sorprendente similitud" (CALLAEY ARRANCIBIA 2005, p. XIII): un símbolo o una palabra poseían una misma esencia en el tiempo y en el espacio. ${ }^{22}$ Esta técnica anticientífica ignoraba así los fundamentos de la sociología, de la antropología y de la etnografía. ${ }^{23}$ Omitía que "los textos circulan sin sus contextos", y que cada

\footnotetext{
${ }_{19}$ Parece sorprendente hablar en éstos términos. Como lo enseñó el historiador libanés Amin Maalouf (2009), la crueldad, la tortura y hasta el canibalismo caracterizaron el comportamiento de estos "peregrinos armados" (CALLAEY ARRANCIBIA 2005, p. 3).

${ }^{20} \mathrm{Al}$ año siguiente, el autor completó: "Las logias masónicas, nacidas en el época de las catedrales, se revelan, a la luz de esta investigación, como las herederas de las estructuras creadas por los monjes constructores que elevaron los grandes templos de la Cristiandad" (CALLAEY ARRANCIBIA 2005, p. 103; 2006).

${ }_{21}$ Modelo explícitamente reivindicado en, por ejemplo, (CALLAEY ARRANCIBIA 2005, p. XI).

22 La técnica de "la sorprendente similitud" fue elevada al rango de método científico. Entre las "pruebas", mencionemos las "espadas, guantes, paramentos propios de la caballería y un sinfín de símbolos y términos provenientes de las órdenes religiosas surgidas en la Edad Media" (CALLAEY ARRANCIBIA 2005, p. XII, 2).

${ }^{23}$ El sentido de un símbolo es relativo a la cultura que le da significación. Antes de ser apropiada por los nazis,
} 
generación cultural los reinterpreta en su propia circunstancia (BOURDIEU, 2002). Descontextualizaban, afirmaban sin probar y citaban sin brindar referencias. Las ocasionales notas bibliográficas revelaban conocimientos historiográficos débiles y azarosos. El relato se tejía impermeable a la opinión científica. Este castillo de naipes se elevaba sobre vulgatas fantasiosas de estilo neotemplario. A esta altura, también se podía adaptar la teoría neocorporativa a América Latina. "Masonólogos" eminentes excavaron los vestigios de una "masonería operativa" medieval en Sudamérica que, curiosamente, también había escapado a los historiadores, sociólogos y arqueólogos (FERRO FAVA 1993).

¿Se trataba de investigación científica o de operación ideológica? Invocando la grandeza de un imperio occidental y cristiano, evocaban "la espiritualidad de Occidente"; ¿existe la espiritualidad de Occidente o las múltiples espiritualidades humanas, de Oriente a Occidente? ¿Se reflejaba así la preocupación de personas incómodas por su "doble pertenencia [...] al catolicismo y a la masonería", deseosas de cristianizar a esta última y de luchar contra "los sectores más agnósticos de la Orden"? Criticaban a los partidarios de la laicidad del Estado, numerosos entre los masones latinos. Comentando la actualidad desde el sueño neomedieval, juzgaban "grave" que el preámbulo de la Constitución Europea no integrara "alguna referencia explícita a las comunes raíces judaico-cristianas, referencia no solo oportuna sino obligada, en tanto la misma masonería tiene sus orígenes en el mismo filón espiritual y cultural" (CALLAEY ARRANCIBIA 2005, p. 1-7, 2006, p. I, XIII, XX). Volviendo a la circunstancia nacional, ¿ podía ser ingenua la asociación, en estas publicaciones, entre masonería, corporaciones, militares e Iglesia católica cuando la Argentina apenas salía de medio siglo de dictaduras y de "golpes cívico-militar-religiosos" (MALLIMACI 1996, p. 182-183)?24

\section{Conclusiones}

Historia y memoria forman una pareja compleja y frecuentemente conflictiva, como lo ilustra el caso de la masonería. Abandonada durante mucho tiempo por los sociólogos e historiadores, ésta se constituyó en objeto de investigaciones científicas a partir de la década de 1950 en Francia, de 1970 en Inglaterra, Escocia, España y Estados Unidos, y de 2000 en América latina. Este campo es novedoso, vasto y fértil.

Verdadera serpiente los mares masónicos, la cuestión de los orígenes es hoy resuelta. Hoy, sabemos con seguridad que el siglo XVIII fue el siglo de la invención de la masonería. Desde 300 años, sin embargo, dos grandes líneas mitológicas han alimentado los imaginarios colectivos sobre este punto. De allí, claro, su pregnancia y su influencia residual. Para los masones de distintos espacios y de distintas épocas, estas matrices (y sus variaciones) proveyeron mitos fundacionales, fuentes de identificación y de legitimación, guías ético-

por ejemplo, la esvástica era el corazón de Buda. Tomemos el ejemplo de un símbolo: el color de duelo. En 1903 (ihace 110 años!), Paul d'Enjoy escribía «Los australianos afectados por un duelo se pintan el cuerpo de blanco, los polinesios de rojo, los negros de África central de amarillo, los indios de América de negro [...] Si el traje de duelo es de color negro en Europa [...], es azul o violeta en Turquía [...], blanco en Japón, en China y en An-Nam»: d'Enjoy (1903).

24 Sobre este tema, véase también: Lafage (1991); Rouquié (1972). 
ideológicas: fueron "invención de la tradición" (HOBSBAWM; RANGER 1983). Repetidas de generación en generación, participaron de la "institución imaginaria de una sociedad", a la que dieron "significaciones imaginarias sociales" autoperpetuadas a través de "la repetición" (CASTORIADIS 2008, p. 122).

Estos mitos ¿son alegorías ideológicas? ¿Son laboratorios de determinada hegemonía cultural? La cuestión es vasta; no puede ser agotada en este artículo. Éste se limitó a identificar el origen de las dos grandes matrices -neoantigua y neomedieval- que dieron a los masones sus mitos fundadores.

Como texto fundador, las Constituciones de 1723 dieron a la masonería un neopasado antiguo. Desde la creación del mundo (estimada en aquella época en unos 4000 años antes de Cristo), una cofradía de artesanos había, de Oriente a Occidente, preservado un método técnico-científico universal, el común patrimonio de la humanidad dividida en idiomas, naciones y religiones. La parábola era cristalina: primera asociación humanas, la masonería tenía por reunir y reconciliar al género humano por encima de sus divisiones nacionales, religiosas y políticas (MOLLÈS 2015b).

Las Constituciones esbozaban una línea de horizonte. Una línea dinámica: lejos de ser monolítico y estático, este texto fue inventado y reinventado y, en 60 años, el libro sagrado cuadruplicó su volumen. Las Constituciones proveían una línea de horizonte cuya nitidez, sin embargo, fluctuaba. Sometida a circuitos de traducción y de difusión azarosos, variaba según los espacios y los tiempos. Así, fueron estudiadas (o no) de diversas maneras según las épocas, los públicos y las regiones. Circularon (o no) sin su contexto, sin llevar consigo el campo de producción del cual eran producto. En efecto, "los textos circulan sin sus contextos" (BOURDIEU 2002) y, más aún, las prácticas sociales circulan sin su teoría. Introducidas en un nuevo campo de recepción, eran reinterpretadas en función de las circunstancias, de los intereses y de la ideología de los traductores y de los receptores.

En determinados contextos, estos vacíos en la memoria colectiva fueron rellenados con neotradiciones alternativas. Los orígenes medieval-caballerescos fueron inventados en 1736 en Francia, adonde la nueva práctica social había llegado sin su teoría y se dirigía a otro público en otro contexto. A la monarquía francesa y su aristocracia, un caballero escocés propuso un mito cobijado por la sombra legitimadora de las Cruzadas. De asilo para la ciencia y el género humano, la cofradía se había convertido en heredera de las órdenes militaroreligiosas, y quizás en expresión del Occidente cristiano frente a los bárbaros asiáticos y a los heréticos.

Así, desde los inicios, surgía una multiplicidad de imaginarios históricos y de memorias colectivas. Dos grandes matrices simbólicas comenzaban a proliferar. ¿Expresaban estructuras del sentimiento e inclinaciones ideológicas disímiles? La segunda parte del artículo no pretende zanjar esta cuestión; apenas propone una indagación preliminar, un primer sondeo de los usos militantes que, desde entonces, participaron de la reproducción de estos imaginarios y de estas memorias colectivas. Primera constatación: estas neotradiciones con frecuencia fueron el producto de operaciones de manipulación sobre la memoria, que no 
debe confundirse con la historia. El mito de los orígenes antiguos parece haber servido frecuentemente a los partidarios del universalismo humanista, de la ideología del progreso y de la modernización. Difícil no ver un paralelo con los filósofos del siglo XVIII, quienes encendieron las luces de la democracia antigua para alumbrar tiempos de oscurantismo y absolutismo. Por el contrario, los relatos neo-medievales y caballerescos parecen atraer a los partidarios de las jerarquías tradicionales, reaccionarios o conservadores. Difícil no ver un paralelo con la aristocracia prusiana que, a partir de mediados del siglo XVIII y más aún de la Revolución francesa, buscó en el romanticismo neomedieval un dique contra la filosofía moderna y el cambio social que minaban su hegemonía.

¿En qué medida puede establecerse un paralelo entre estas estructuras del sentimiento, estas sensibilidades ideológicas y los dos linajes mitológicos evocados? Para responder a esta pregunta de manera firme, un nuevo texto es necesario. Éste deberá interrogar la genealogía de ambos linajes, enfatizando sobre las condiciones sociales de producción y de circulación: más allá de la variante, más allá de la forma explícita, interrogar a los contextos, los actores y las filiaciones. Realizado este programa, se podrá interrogar una intuición: la experiencia de terreno sugiere que, antes de 1950, la prensa y la correspondencia de los masones latinoamericanos remitían -en cuanto a los orígenes- al siglo XVIII, la Ilustración y la Revolución francesa. Las referencias neomedievales parecen haber sido ausentes, o por lo menos rarísimas. Hoy, por el contrario, gran parte del público masónico latinoamericano se focaliza sobre estos mitos,

152 que asimila a verdades históricas. ¿Cómo explicarlo? ¿Puede verse un paralelo con la Guerra fría, la hegemonía cultural estadounidense y la ola anticomunista? Como se ve, la cuestión abre perspectivas atadas a un pasado todavía presente.

\section{Referencias bibliográficas}

ANDERSON, B. Imagined Communities: Reflections of the Origin and Spread of Nationalism. London: Verso, 1983.

ANDERSON, J.; DÉSAGULIERS, J.-T. The Constitutions of the Free-Masons, containing the History, Charges, Regulations \&c. of that Most Ancient and Right Worshipful Fraternity. London: William Hunter, 1723.

. The New Book of Constitutions of the Antient and Honourable Fraternity of Free and Accepted Masons, containing Their History, Charges, Regulations, \&c. London: Caesar Ward, 1738.

ANDERSON, J.; DÉSAGULIERS, J.-T.; JOUIN, E. Livre des constitutions maçonniques: reproduction du texte original anglais de 1723 . Paris: Emile-Paul, 1930.

BAUMAN, Z. Modernidad líquida. México: FCE, 2003.

BOURDIEU, P. Les conditions sociales de la circulation internationale des idées. Actes de la recherche en sciences sociales. La Circulation internationale des idées, n. 145, p. 3-9, 2002. 
CALLAEY ARRANCIBIA, E. Ordo laicorum ab monacorum ordine: Los Orígenes Monásticos de la Francmasonería. Buenos Aires: Academia de Estudios Masónicos, 2004.

. El otro Imperio Cristiano: De la Orden del Temple a la Francmasonería. Madrid: Nowtilus, 2005.

Ordo laicorum ab monacorum ordine: La masonería y sus orígenes cristianos. Buenos Aires: Kier, 2006.

CANNADINE, D. The Context, Performance and Meaning of Ritual. The British Monarchy and the "Invention of Tradition", c. 1820-1977. In: HOBSBAWM, E. J. E.; RANGER, T. (eds.). The Invention of Tradition. Cambridge: Cambridge University Press, 1983. p. 101-164.

CASTORIADIS, C. Psicoanálisis y política. In: EI mundo fragmentado. La Plata: Terramar, 2008. p. 115-129.

COMBES, A. Les trois siècles de la franc-maçonnerie française. Paris: Edimaf, 1998.

DACHEZ, R. L'invention de la franc-maçonnerie: Des Opératifs aux Spéculatifs. Paris: Véga, 2008.

DEL SOLAR, F. S. Reseña del II Seminario euro-argentino de historia de las redes masónicas atlánticas (Buenos Aires, Argentina, 2014). Revista de Estudios Históricos de la Masonería Latinoamericana y Caribeña, v. 6, n. 2, p. 139-145, 2014.

D'ENJOY, P. Des signes extérieurs du deuil. Bulletins et Mémoires de la Société d'Anthropologie de Paris, v. 4, n. 1, p. 112-116, 1903.

FERREIRA, V. C. Entre emancipadas e quimeras: imagens do feminismo no Brasil. Cadernos del Arquivo Edgard Leuenroth, n. 3, 1996.

FERRER BENIMELI, J. A. Aproximación a la historiografía de la masonería latinoamericana. Revista de Estudios Históricos de la Masonería en América Latina \& el Caribe, v. 4, n. 1, p. 2-120, 2012.

FERRO FAVA, J. F. Tres momentos en la historia de la masonería en América. In: FERRER BENIMELI, J. A. (ed.). Masonería española y América. Actas del Symposium Internacional de Historia de la Masonería Española. Zaragoza: CEHME, 1993. v. 1, p. 257-269.

GOULART DA SILVA, M. Maçonaria no Brasil. História, Política e Sociabilidade. Jundiaí: PACO EDITORIAL, 2015.

GOULD, R. F. Gould's History of Freemasonry Throughout the World. New York: Charles Scribener's Sons, 1936.

HARRISON, D. Are there any connections between the Knight Templar and Freemasonry? London: Lewis Masonic, 2014. Disponível em: http:// www.youtube.com/watch?v=vOc_8ThDrLQ\&feature=youtube_gdata_ player. Acesso em: 26 maio. 2014. 
HOBSBAWM, E. J. E.; RANGER, T. (eds.). The Invention of Tradition. Cambridge: Cambridge University Press, 1983.

KAUTSKY, K. El cristianismo: sus orígenes y fundamentos. Buenos Aires: Marat, 2013 [1908].

LACERDA DE MOURA, M. A mulher e a maçonaria. Conferencia realizada em sessão magna branca da Aug.•. \& Resp.•. Loj.•. Cap.•. Fr.•. "14 juillet". São Paulo, Loge française 14 juillet, 1922.

LAFAGE, F. L'Argentine des dictatures (1930-1983): Pouvoir militaire et idéologie contre-révolutionnaire. Paris: L'Harmattan, 1991.

LASSALLE, P. Le Discours de Ramsay (1736). In: MOLLIER, P. et al. (eds.). Les plus belles pages de la franc-maçonnerie française. Paris: Dervy, 2003, p. 38-41.

LE GOFF, J. História e memória. Trad. Bernardo Leitão. Campinas: Ed. UNICAMP, 1990.

LIGOU, D. (ed.). Dictionnaire de la franc-maçonnerie. Paris: PUF, 1998 [1974].

MAALOUF, A. Las cruzadas vistas por los Árabes. Madrid: Alianza, 2009.

MALLIMACI, F. H. Catolicismo y militarismo en Argentina (1930-1983), De la Argentina liberal a la Argentina católica. Revista de Ciencias Sociales, n. 4, p. 181-218, 1996.

MANSUR BARATA, A. Freemasonry in Brazil (Nineteenth Century): History and Sociability. Revista de Estudios Históricos de la Masonería en América Latina \& el Caribe, Número especial / Special Issue UCLA Grand Lodge of California, p. 137-151, 2013.

MARINHO DE AZEVEDO, C. M. Maçonaria, anti-racismo e cidadania. Uma história de lutas e debates transnacionais. São Paulo: Annablume, 2010.

MARTÍNEZ ESQUIVEL, R. Hacia la construcción de una historia social de la masonería en Centroamérica. Estudios, n. 27, 2013.

MOLLĖS, D. Un Puente transatlántico: la masonería hispano-argentina en la circunstancia euro-americana de Entre-Guerras. In: FERRER BENIMELI, J. A. (Ed.). La masonería española en la época de Sagasta. Actas del Symposium Internacional de Historia de la Masonería Española. Zaragoza: CEHME, 2007. v. 2, p. 809-842.

MOLLÈS, D. Franc-maçon, socialista de esquerda e antifascista: o exilio euroamericano de Francesco Frola. In: AARÃO REIS, D.; ROLLAND, D. (eds.). Intelectuais y modernidades. Rio de Janeiro: FGV, 2010, p. 112-141.

- Exiliados, emigrados y modernizadores: el crisol masónico euro argentino (Europa- Rio de la Plata, 1840-1880). In: FERRER BENIMELI, J. A. (Ed.). La masonería española: represión y exilios. Symposium 
internacional de historia de la masonería española. Zaragoza: CEHME, 2011. v. 1, p. 47-70.

- Triángulo atlántico y triángulo latino: América Latina y el sistema-mundo masónico (1717-1921) (Elementos para una historia de la opinión pública internacional). PolHis, Revista del Programa Interuniversitario de Historia Política, Mar del Plata: UBA, UNICEN, UNLP, UNMdP, UNS, UNSAM. n. 12, p. 352-355, 2013.

- L'histoire globale et la question maçonnique: éléments pour une analyse. Revista de Estudios Históricos de la Masonería en América Latina \& el Caribe, v. 6, n. 1, p. 3-33, 2014.

. La invención de la masonería. Revolución cultural: religión, ciencia y exilios. La Plata: EDULP, $2015 a$.

. "Esta religión sobre la cual todos los hombres concuerdan": la invención de la masonería, una revolución cultural entre religión, ciencia y exilios. Revista Brasileira de História das Religiões, Universidade Estadual de Maringá. v. 8, n. 23, p. 176-211, out. 2015b.

Freemasonry and Templarism. In: SNOEK, J. A. M.; BOGDAN, H. (eds.). Handbook of Freemasonry. Leiden (Netherlands): Brill, 2014. p. 8299.

MOREL, M.; DE OLIVEIRA SOUZA, F. J. 0 poder da maçonaria: a história de uma sociedade secreta no Brasil. Rio de Janeiro: Nova Fronteira, 2008.

ÖNNERSFORS, A. The Cosmopolitan Foundations of Freemasonry. CRFF Working Paper Series, University of Sheffield. n. 3, p. 1-32, 2010.

PAILLARD, M. (ed.). The English and French Masonic Constitutions. An authentic account of the divergent Constitutions of the United Grand Lodge of England and the Grand Orient of France, compared with their original joint authority. London: M. Paillard, 1938.

. (ed.). Reproduction of the "Constitutions of the Free-Masons or Anderson's Constitutions" of 1723 in English and French. London: M. Paillard, 1952.

PORSET, C. De la régularité en maçonnerie, Notes d'histoire. In: BAUER, A. (ed.). De la régularité maçonnique. Paris: Edimaf, 1999. p. 23-45.

REHMLAC +. Plataforma científica. IV Simposio Internacional de Historia de la Masonería y los Movimientos Asociativos Latinoamericanos y Caribeños. San José, Costa Rica: Universidad de Costa Rica, REHMLAC +, Universidad de Zaragoza, CEHME, Universidad de La Habana, UCLA, 2-8 nov. 2015. Disponível em: http://simposiomasoneria.ucr.ac.cr/.

RÉVAUGER, C. English Freemasonry during the Enlightenment: how radical, how conservative? Lumières, Revue du Centre interdisciplinaire bordelais d'étude des Lumières, n. 22, p. 33-49, 2013. 
ROCK, D. Latin America in the 1940's: War and Post-War Transitions. Los Angeles: University of California Press, 1994.

ROLLAND, D. La crise du modèle français. Mariane et l'Amérique latine. Culture, politique et identités. Rennes: PUR, 2000.

ROUQUIÉ, A. Intégristes et militaires, Les tentatives du nationalcatholicisme en Argentine. Paris: CERI, 1972.

SMITH, A. D. The Nation: Invented, Imagined, Reconstructed. Millennium. Journal of International Studies, v. 20, n. 3, p. 353-359, 1991.

STEVENSON, D. The Origins of Freemasonry: Scotland. In: SNOEK, J. A. M.; BOGDAN, H. (eds.). Handbook of Freemasonry. Leiden: Brill, 2014, p. 50-62. 